\title{
LABOR MOBILIZATION IN THE NATIONAL SOCIALIST NEW ORDER
}

\author{
Franz NeumanN*
}

The white race can maintain its position in practice only if the differences in the living standards in the world are retained. Give to our so-called export markets the same living standards that we have, and you will find that the preponderance of the white race, which is expressed not only in the political might of the nation but also in the economic position of the individual, can no longer be retained.

Thus spoke Adolf Hitler to an audience of Rhineland industrialists on January 27, 1932-one year before he came to power. ${ }^{1}$ In October, r94I, Ernst Poensgen, president of the United Steel Trust, celebrated his seventieth birthday. On behalf of Adolf Hitler, the Minister of Economic Affairs presented him with the Order of the Eagle accompanying the presentation with the following speech:

With the overthrow of bolshevism and the development of the vast Eastern European continent, entirely new and extremely favorable prospects for German business will be opened up. This applies also to the German iron industry. This expansion also offers possibilities for a revision, long overdue, of price and profit policy in the coal and iron industries. ...2

Better than the many ideological treatises on Lebensraum, geo-politics and racialism, these two statements reveal the kernel of the National Socialist doctrine: it is the old German imperialism with new methods, new techniques and new ideologies. It aims at subjecting Europe to the total economic control of German industry and reserving the exploitation of that vast continent exclusively for German masters. But economic exploitation by economic means alone, or by the methods of liberal democracy, or even of Wilhelminian absolutism, is no longer possible.

\footnotetext{
* J.D., I923, University of Frankfort o.M.; Ph.D., I936, University of London. Visiting Lecturer, Columbia University, 1942-1943; Consultant, U. S. Board of Economic Warfare, since 1942; Member, Institute of Social Research, Columbia University, since 1936. Member of the Berlin Bar; counsel to German trade unions; Lecturer, German School of Politics, Berlin; Lecturer, Labor Academy, Frankfort o.M.; Member of the Administrative Court of Prussia, 1927-1933; Expert on Cartel Reform for the Reich Econonic Council, 1931-1932. Author: Koalitionsfreineit und ReIchsverfassung (Berlin, 1932); DAs Gesamite Pressenotrecht (Berlin, I933); European Trade Unionism and Politics (1935); Behemoth: the Structure and Practice of National Socialism (1942). Contributor to legal and social science periodicals.

1 Vortrag adolf Hrtzers vor westdeutschen Wirtschaftlern im INDUStrieklub zu Düsseldorp AM 27. Jandar 1932 (Munich, r932) 13, quoted from the author's Behemoth: THE StructurEe AND Practice of National Socialism (New York, 1942) (hereinafter referred to as "Behemoth") 183.

${ }^{2}$ Berliner Börsenzeitung, Oct. I8, 1941, quoted from International 'Transpont Workens' Federation Bulletin No. 23, Fascism, Nov. Io, 194 I (hereinafter referred to as "I. T. F. Bull.").
} 
Both the domestic situation and the political structure of Europe made it impossible to maintain total economic supremacy without corresponding total political supremacy. Internal conditions made it impossible since the German people were unwilling to resort to aggressive war in order to establish their supremacy. ${ }^{3}$ War today is total war, requiring the total organization of society even in times of peace. Even the legal distinction between war and peace is being slowly abandoned. Peace seems merely a preparatory period of war. A total organization of society for aggressive war cannot be achieved within the framework of political democracy. This is the view of General Ludendorff as of J. A. Hobson." Nor can war today be organized by mere absolutism, that is, by the establishment of a central economic machinery independent of the social forces underlying it. Total war requires total ideological, economic, social, and military organization of society; it makes necessary the complete control of every aspect of social and private life. This, obviously, cannot be achieved by a bureaucracy which, to be effective everywhere, would have to expand to an unprecedented size. In consequence, a number of mechanisms have to be built up: business organizations for the complete control of business; the military machine; the civil services for the swift and efficient execution of the commands of the top leadership; and a monolithic party for "Menschenführung"for the indoctrination and manipulation of the masses of the people.

Hitler's Düsseldorf speech of $193^{2}$ contains the kernel of the doctrine of racial imperialism, ${ }^{5}$ that is, of the theory that the present war is a war of a proletarian race against plutocratic democracies, a doctrine that was fully developed by the Italian nationalist Enrico Corradini during the Turkish-Italian conflict. It is undoubtedly the most genuine and the most dangerous manifestation of the National Socialist spirit.

This doctrine makes the war a paying proposition for the German people. It is not mere propaganda. It is even now a reality. German propaganda is never mere propaganda, it is always action and propaganda. In almost every case it contains a token fulfillment of its promises. National Socialists do not content themselves with making anti-Semitic propaganda, they actually exterminate the Jew; they do not revile liberalism and democracy, they actually annihilate them; not only do they call themselves a proletarian race engaged in struggle with plutocratic nations-but, even during the war, begin to carry out the promises of their propaganda. ${ }^{6}$ Indeed, many groups in German society have actually profited from for-

3 $C f$. BeHeMoth $185-186$.

See Behemotr 185 .

"On the evolution of the doctrine, see BEнEмоTн 184-218.

- This insight into the intrinsic connection between National Socialist propaganda and action should, rightly understood, make two things clear. First: No German victory has been won by propaganda; neither the destruction of democracy in Germany, nor the defeat of France are the work of superior propaganda techniques. Second: No mere propaganda of the Allied powers against Germany will have the slightest success unless such propaganda is backed by the beginning of performance. I cannot here dwell upon this important problem. The author has, in cooperation with Dr. Norbert Guterman, prepared a memorandum in which the principles of our psychological offensive against Germany are explained. 
eign conquests. The party with its Hermann Göring combine and its Wilhelm Gustloff Foundation, its Labor Front business organizations, ${ }^{7}$ has incorporated many industrial, commercial and banking enterprises into its own organizations. Big business has swallowed enormous slices of foreign enterprises in the process of Germanization. ${ }^{8}$ Thousands of new positions have been created in the occupied territories filled from the rank of the party officials, thus from the middle classes whose economic independence has been destroyed by the process of monopolization which is the decisive feature of the structural changes in German economy.

All these groups have indeed benefited. They are tied to the party and to the military machine by bonds of gold. They are, thereby, also bound to the régime by a collective guilt: the spoliation of the conquered lands by army, party, bureaucracy, and big business makes every one of them a partner in a conspiracy; each of them shares the guilt of a ruthless and immoral conqueror. They must stick together to the bitter end, hoping to avert disaster by maintaining unity.

We have not mentioned the working classes, workers and salaried employees. Do they actively share in the process of spoliation? Are they members of the master race that maintains and even improves its status at the expense of the masses in the conquered territories? Or are they victims of an exploiting machine that subjects them to terror equally with the masses in the conquered countries?

This is the crucial question. It is crucial for the understanding of the origin, nature and aims of National Socialism; the answer to it must determine the character of our psychological offensive against Germany and of the peace that we want to make. The significance of the problem is well realized by National Socialists. Slogans such as "plant community," "people's community" and "antiplutocratic struggle" are designed to capture the working classes. Yet it is precisely on this point that the National Socialist régime offers only propagandanothing else.

The German worker or salaried employee has received nothing from the régime except promises of a better future. He had, it is true, obtained security before the outbreak of the war. Full employment was the only achievement of the National Socialists. Yet that security is extremely ambiguous. It has paved the way for the utmost physical insecurity, namely for death. Those workers who did not know it before, know it since 1939: that economic security under National Socialism was possible only as a prelude to death. Death in the trenches, death in air raids, death in the factories as. a result of physical exhaustion, death in railroad yards, chemical factories, and the like as a result of a terrific increase in industrial accidents. The connection between economic security and death is not incidental, it is essential; it springs from the very nature of National Socialism, which is an aggressive imperialist system seeking to transform markets into colonies.

How then have the working classes been integrated into the National Socialist

${ }^{7}$ See the detailed discussion in BeHEMOTH 298-305.

"Id. $180-184,275-277,386-388,396-398$. 
system? Certainly not by voluntary collaboration with the régime. Even if the working classes wanted to collaborate actively, they could not do so since they are the only groups in society that do not possess organizations of their own and thus have no means of articulating either acceptance or rejection of the régime. The German Labor Front is-as we shall see-neither a trade union nor a substitute for it. It is entirely a terroristic agency of the party. Psychologically, the attitude of the workers may be described as one of passive acceptance of National Socialism, a passivity produced by the ideological and organizational collapse of the trade unions and of the working class parties, by the severe unemployment from 1930 to 1933, and by the suicidal policy of the Weimar Republic. Economically, the system makes use of the oldest capitalistic incentives to increase production, viz., what is called in Germany "Leistungslohn"-"performance wage"-a combination of time and piecework where piecework elements predominate over time elements, a kind of streamlined Bedaux system with universal application-even to juveniles. Socially the work is incorporated into the system by terror, a terror as subtle as the system itself, by the destruction of rational, hence calculable, relations and their replacement by the unexpected.

The following discussion will deal with the control of labor not only in Germany, but in the occupied territories as well. It will be based exclusively on German materials. Some of the materials are already discussed in my book, "Behemoth," but this article will supply many additional data that have heretofore not been discussed.

\section{The German Labor Supply}

For an understanding of the magnitude of the problems of labor control in Germany, some data on the composition of its working population are necessary. Of the total population in I939 of $79,400,000$, approximately $39,800,000$ (50.1\%) were gainfully employed. The gainfully employed group was composed of $24,900,000$ men ( $64.1 \%$ of the male population) and $14,900,000$ women $(36.7 \%$ of the female population). In the old Reich territory with a total population of $68,128,000,18 \%$ were engaged in agriculture and forestry; $41 \%$ in industry and handicrafts; $15.8 \%$, in commerce and transportation; and $10.1 \%$, in public and private services. Household service accounted for $2.1 \%$ and the remainder, $13 \%$, were classed as "independents without occupation." 10 Such is the normal picture of a highly industrialized, highly monopolized, and highly bureaucratic society.

In the period 1933 -I939 there had been a sharp increase $(34.2 \%)$ in the total number engaged in public and private services, much smaller increases in industry

\footnotetext{
${ }^{9}$ The discussion is based on the results of the 1939 Census, as published in (r94I) WrRTscraft UND Stattstrx, No. 2; (1941) id. No. 3; (1941) 50 Soziale Praxis, Nos. 2, 8. The territory comprises the former German Reich, Austria (called "Ostmark") and the Sudetenland.

${ }^{20}$ These are essentially recipients of annuities, pensioners, persons living on their own capital, or persons supported by others not members of their households. STATISTISCHES JAHRBUCH F. D. DeUTSChe ReICH (1938) $24 \mathrm{n}$.
} 
$(8.6 \%)$ and in domestic services $(7.8 \%)$, and declines in agriculture and forestry (I0.6\%) and in commerce and transportation (3.\%\%). Independents without occupation also declined $1.2 \%$. Of the gainfully employed (including their families), $7 \%$ in 1939 were civil servants, $13 \%$ were salaried employees, and $52.8 \%$ were wageearners. These groups had increased by $10.2 \%, 17.1 \%$ and $6.6 \%$, respectively, in the period between 1933 and 1939 while the total occupied population was increasing by $3.9 \%$.

In the boom year 1929 the total number of wage-earners and salaried employees actually employed was $17,870,000$. In January, 1941, this total had risen to an estimated 22,670,000 (I4,250,000 men, 8,420,000 women), ${ }^{11}$ to whom about 2,100,000 foreign civilian workers should be added. ${ }^{12}$ In February, 1942, approximately $24,000,000$ (15,000,000 men and 9,400,000 women) were at work. To these should be added an unknown number of war prisoners, of whom there were $1,400,000$ by April $x$, $194 \mathrm{x}$, all Polish or French. ${ }^{13}$ This increment has brought the total to about 27,000,000.

The consideration of the problem of mobilizing this vast labor force may be organized under the following heads:

The institutional arrangements for controlling the labor market.

The devices used for increasing and distributing the labor supply.

The probable consequences of the National Socialist labor policy for the future development of Germany and Europe.

\section{The Control of the Labor Market}

We are not concerned with the stages of German policy regarding the control of the labor supply. We may, with the German authority in the field, ${ }^{14}$ distinguish four such stages and add a fifth:

(I) the general struggle against mass unemployment, ${ }^{15}$ which has been carried out primarily by pump priming and public works;

11 (i94I) 50 Soztale Praxis, No. 5, p. I99; Behemonth 508-509.

12 The latest detailed analysis, as of Sept. 19, 194I, based on official German sources, is contained in I. T. F. BurL. No. 4, Feb. 5, r942. It is as follows:

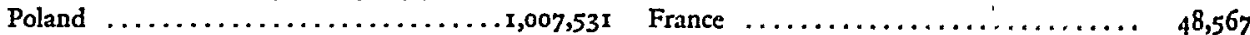

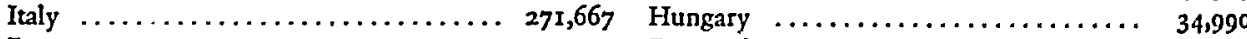

Protectorate $\ldots \ldots \ldots \ldots \ldots \ldots \ldots \ldots \ldots$ 140,052 Denmark $\ldots \ldots \ldots \ldots \ldots \ldots \ldots \ldots \ldots$ 28,895

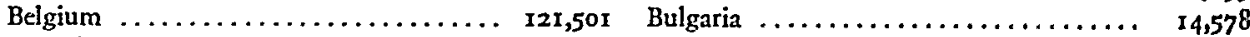

Yugosiavia $\ldots \ldots \ldots \ldots \ldots \ldots \ldots \ldots \ldots$ ro 8,791 Miscellaneous $\ldots \ldots \ldots \ldots \ldots \ldots \ldots \ldots$ 189,919

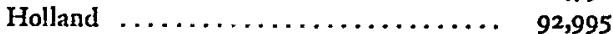

Slovakia $\ldots \ldots \ldots \ldots \ldots \ldots \ldots \ldots \ldots$ 80,037 Total $\ldots \ldots \ldots \ldots \ldots \ldots \ldots \ldots .2,139,553$

All the figures, with the possible exception of the Protectorate whose labor supply seems to be exhausted, have considerably increased during the past few months.

${ }^{13} 21$ WrRtschaft und Statistax (194I) roo; Frankfurter Zeitung, Aug. 1o, 1941.

${ }^{14} \mathrm{~F}$. Syrup (President of the Reich Institute for Labor Exchange and Unemployment Insurance and Secretary of State in the Ministry of Labor), Die Etappen des Arbeitseinsatzes (1939) 48 Sozinle Praxis, No. r, p. 7; Syrup, Zehn Jahre Reichsanstalt für Arbeitsvermittzung und ArdeitslosenVERSICHERUNG I927-r937 (Berlin, I937).

${ }^{15}$ This aspect of Germany's efforts is very well presented by Leo Grebler, Work Creation Policy in Germany r932-1935 (1937) 35 INT. LAB. REv. 33I-35I, 505-527. 
(2) the control of the utilization of the unemployed in 1934 and 1935 with its Act of May 15, I934, for the Regulation of Labor Supply ${ }^{16}$ and its Decree of August 10, 1934, on the Distribution of Labor Forces; ${ }^{17}$

(3) the beginning of labor scarcity and the control of the natural fluctuations of labor-especially in the many regulations of November 7,1936 , issued under the authority of the Four-Year-Plan Decree and discussed herein;

(4) the securing of adequate labor supply for tasks of major political significance on the basis of the decree of June 22,$1938 ;^{18}$ and we may add

(5) the complete control of the labor supply in all its aspects with the outbreak of the war by the decree of September I, I939, of the Ministerial Council for the Defense of the Reich. ${ }^{10}$

We shall not dwell on the first phase, but concentrate on the policy during the preparedness and war periods.

The institutions responsible for the increase and distribution of labor supply and the increase of labor productivity are ( $\mathrm{I}$ ) state organs, namely, (a) the labor exchanges directed by the Ministry of Labor, and (b) the Trustees of Labor, Labor Courts, and Social Courts of Honor; (2) party organs, namely, the Labor Front, the Councils of Trusted Men, the plant troops and political shock troops; and (3) a combination of both, namely, the general deputy for labor supply, the "combingout" commissions and party district leaders. We shall devote our attention to each of these institutions in turn.

\section{I(a). The Labor Exchanges}

Up to the spring of 1942 , the total power over the labor supply was vested in the Ministry of Labor acting through its executive machinery, the provincial and local labor exchanges, originally organs of the Reich Institute for Labor Exchange and Unemployment Insurance established by the Act of July $16,1927 .^{20}$ The Reich Institute was a semi-autonomous institution, comprising a main office, 13 provincial labor exchanges, and 345 local labor exchanges. ${ }^{21}$ The composition of these bodies follows the principle of a democratic and pluralistic collectivism prevalent under the Weimar Republic. They comprised representatives of trade unions, employers, associations, and public authorities controlled by the Minister of Labor. The Reich Institute performed-as its name indicates-a dual function: (I) it raised contributions for unemployment insurance, administered the funds and provided for insurance; and (2) it organized employment service. However, it had no monopoly in this. Although private labor exchanges conducted on a business basis were

\footnotetext{
${ }^{10}$ Reichsgesetzbiatt (hereinafter referted to as "R. G. Bz.") pt. I, $38 \mathrm{r}$.

${ }^{17}$ Id. 786. Both devices will be discussed below.

18 $1 d$. 652 , discussed below, together with the later Decree of Feb. 13, 1939.

${ }^{20}$ Id. 1685 .

${ }^{20} I d$. 187 , later amended.

21 At present there are 23 provincial (state) and 468 local employment offices. See Beisiegel, Labor Redistribution in Germany (1942) INT. LAB. Rev. No. 4, p. 400.
} 
prohibited as of January I, I93I, by the order of April $28,1923,{ }^{22}$ and the commercial agencies indemnified, non-profit organizations (except political organizations) such as employers associations, trade unions, and religious and charitable bodies could still act as labor exchanges. Moreover the employer could hire labor by whatever means he thought fit; he could advertise or utilize non-profit organizations or his own personnel department. The trade union demand for a state monopoly of labor exchange failed of realization under the Weimar Republic.

The changes under National Socialism affected, of course, the composition of the agencies of the Reich Institute and do not concern us here. However, the increasing necessity for close centralization of the control of labor soon led to a complete organizational change. The main office of the Reich Institute was transformed into a "Reichsstock fïr Arbeitseinsatz," a Reich Fund for Labor Supply, ${ }^{23}$ i.e., a fund that merely administers the contributions paid by employers and employees ( $6 \frac{1}{2} \%$ together) and defrays the costs of the labor supply administration. The executive offices, the provincial labor exchanges and labor exchanges, have ceased to be the agents of the Reich Institute and have become direct executive agents of the Ministry of Labor. ${ }^{24}$

Shortly afterwards (August $x$, I939) the labor exchanges were also made agencies of the Trustees of Labor with whose tasks we shall deal later. The Trustees, to cope with the increasing amount of their work, had established branch offices which were dissolved in 1939, and their functions are now performed by the labor exchanges, now numbering 468 and staffed by about 45,000 employees. ${ }^{25}$

\section{I(b). The Trustees of Labor, Labor Courts, and Social Courts of Honor}

The power to regulate wages and labor conditions is vested exclusively in the Reich Trustees of Labor as provided for in the Act of January 20, 1934, for the Regulation of National Labor, ${ }^{28}$ the so-called Charter of Labor. The rights of the Trustees of Labor may be grouped under the following heads: (a) they cooperate in the establishment, operation and dismissal of the Councils of Trusted Men; (b) they decide upon mass dismissals; (c) they participate in proceedings before the Social Courts of Honor; (d) they supervise the execution of plant regulations; (e) they enact and supervise wage regulations (Tarifordnungen); and ( $f$ ) they report to the Ministry of Labor. The Trustees of Labor are thus the successors, so to speak, of the collective agreements between employers or employers associations and trade unions.

22 (r923) Reichsarbeitsbiatt 284, later amended by Decree of Sept. 28, 1927, R. G. Bi. pt. I, 318, and then incorporated in $\$ 55$ of the Act of July $x 6,1927$.

${ }^{23}$ Dr. Zschucke in I Posse, Syrup, LANDFried, Backe, Alipers, Kommentar zur ReichsverteidigungsgesetzGebung (hereinafter referred to as "POsse et AL., KommentaR") (Munich \& Berlin, 1939) pt. II, Arbeitslosenhilfe, 2.

${ }_{21}^{2}$ (1939) 48 Soziale Praxis, No. 15, p. 910. 25 Ibid. See also Beisiegel, supra note 2I.

${ }^{28}$ R. G. BL. pt. I, 45. A corresponding statute was enacted on March 23, 1934, for workers and salaried employees (not civil servants) in public administrations and certain publicly owned enterprises (utilities). Id. 220. 
Yet there exist a number of differences. The provisions of the collective agreements normally affected labor contracts only if both parties to the labor contracts were members of the bargaining associations, ${ }^{27}$ though collective agreements might be extended to outsiders by an award of the Minister of Labor on application of a bargaining association. The wage orders of the Trustees, however, automatically affect all employers and employees of a designated industry or craft in a specific region. Still more important is a second distinction. Under the Republic, the collective agreement had precedence over a plant agreement concluded between the employer and the work council. ${ }^{28}$ It is in this provision that the collective character of republican labor relations was most strongly expressed. The Charter of Labor has reversed the relation between plant regulation and wage regulation. According to Section 32, the Trustee of Labor shall issue general wage regulations for "a group of plants" only if such regulations are urgently needed for the protection of the employed. The Charter of Labor thus conceived of plant regulation and individual bargaining as the normal type of labor control, thereby expressing the one fundamental principle of National Socialist methods of mass manipulation: to destroy whatever affinities common work creates and to manipulate the working class by their thorough atomization. ${ }^{29}$ In practice, however, the demands of a highly rationalized and industrialized society proved stronger than the ideas of the Charter of Labor. Even a slight perusal of the Reichsarbeitsblatt, the official periodical of the Ministry of Labor which contains all the regulations of the Trustees of Labor, shows that supra-plant regulation absolutely predominates over plant regulation. However, again a word of warning is necessary. According to the fourteenth administrative order ${ }^{30}$ under the Charter of Labor, the Trustees of Labor may exempt "specific plants or divisions of plants or specific followers"31 (i.e., workers and salaried employees) from all or some provisions of their wage regulations. These exemptions need not be published in the Reichsarbeitsblatt-so that even the statistics of hourly earnings according to wage regulations lose much of their importance.

Gradually, the powers of the Trustees have been freed from the fetters of rational law. The development tended to transform the minimum wage regulation into maximum wage rules. The first basic enactment to this effect was the Decree of June $25,193^{8}$, for the Establishment of Wages. ${ }^{32}$ It again gave the Trustees

${ }_{27}$ Tarifvertragsordnung, Dec. 23, 1918, as re-enacted March I, 1928, R. G. Bt. pt. I, 47.

28 Work Council Act of Feb. 4, I920, 8 , R. G. BL. pt. I, 147.

${ }^{20}$ On the principle of mass manipulation, cf. BEHEMOTH $400-403$.

${ }^{\circ 0}$ German laws, normally "passed" by Hitler alone or jointly with any or all Reich Ministers, usually contain authorizations to one or more officials (as a rule, the ministers concerned) to regulate all details of the enactment by order ("Rechtsverordnungen und allgemeine Verwaltungsvorschriften" or "Durchführungsvorschriften"). Actually, of course, the laws delegate legislative authority. The regulations issued in pursuance of such delegated authority are here translated by the term "administrative order." The term "act" or "decree" is used to refer to the delegating Icgislation.

${ }^{32}$ Order of Oct. 15, r935, R. G.. BL. pt. I, 1240.

32 R. G. BL. pt. I, 691, issued in pursuance of the Four-Year-Plan Decree. 
authority to supervise the wages and labor conditions, to enact such measures as are necessary to prevent any injury to the execution of the Four Year Plan, and to fix maximum wages even by interfering with existing plant regulations and labor contracts. Such maximum wages were fixed in the two branches most affected by labor scarcity, building construction and metal industries, so as to prevent the pirating of labor. The Decree of June 25, 1938, had but little success. Moreover, it did not interfere with acquired rights and still restricted the 'Trustees to the enactment of general regulations. ${ }^{33}$

These powers were added during the war. The Decree of September I, r939, enabled the Trustees to enact wage regulations for individual plants, to dispense with consultation with the committee of experts (for which the Charter of Labor had provided), that is, to speed up the process of wage regulations and to differentiate as finely as necessary even within each industry or craft. The War Economy Decree of September $4,1939,^{35}$ has finally removed all remaining fetters.

It authorizes the Trustees, on the basis of orders from the Minister of Labor, "to adjust at once the earnings to the conditions of war and to fix maximum wages, salaries and other labor conditions by wage regulation." The Decree thus interferes with acquired rights-no matter whether derived from statutes, wage regulations, plant regulations, or individual labor contracts. If, for instance, a plant must be closed down as a result of the war, the Trustee is empowered to dispense with or shorten the dismissal period, however established. ${ }^{30}$ Savings that accrue to the employer must be delivered to the federal tax offices. ${ }^{37}$

Yet, the same War Economy Decree ${ }^{38}$ also restricted the powers of the Trustees by freezing wages, salaries, and all other remuneration. The prohibition to raise the compensation of labor includes piecework, and is ruthlessly enforced. ${ }^{30}$ But the wage freezing seriously lessens the one incentive on which the régime has relied to raise the productivity of labor: the "performance wage" which has been applied even in the case of juvenile workers. ${ }^{40}$ To exempt anyone from the wagefreezing order in order to stimulate production would have meant to sacrifice the very principle upon which the social and economic policy of the war régime rests. It would have unfettered a serious competition for manpower among the business

as Some trustees apparently believed that the Decree of June 25,1938 , authorized them to interfere with specific labor contracts. One such case is reported by Meissinger, (1938) Der Deursche Volkswint No. 46. The problem is discussed by Lutz Richter, Zum Aufgabenkreis des Reichstreuhänders (1938) 47 Soziale Praxis, No. 17, p. I067.

${ }^{34}$ Verordnung zur Abänderung tund Ergänzung von Vorschriften auf dem Gebiete des Arbeitsrechts (Order amending and supplementing Orders relating to labor law), R. G. BL. pt. I, I683.

${ }^{35}$ Id. 1609.

${ }^{\text {so }}$ First Administrative Orders under the War Economy Decree of Scpt. 16, 1939, R. G. Br. pt. I, 1869, and I Posse ET AL., Kommentar, pt. II, Kriegslöhne und -urlaub, 6-r r.

${ }^{37}$ Decree of Oct. II, 1939, R. G. Bl. pt. I, 2053; I Posse et aL., Kommentar II-I3.

${ }^{38}$ Second Administrative Orders of Oct. 12, I939, R. G. BL. pt. I, 2028; I POSSE ET AL., 14-20.

${ }^{50}$ No bonuses may be granted if not granted before Nov. 16 , 1939 (1939) ReichisaraeitsBLATT, pt. I, 544. Interest rates paid by plant savings bank may not be increased. March 8, 1940, (1940) id. 447.

${ }^{10}$ On performance wage, see BeHEMorm 432-433; on piccework for juveniles, see (r94I) so SozisLe Praxis 25I. 
combines, would have threatened the price structure and, perhaps, even paved the way for inflation. The ingenious device used by the régime was to lower the maximum wage if the performance of the worker slackens ${ }^{41}$-so that a minimum effect of the performance wage may be achieved without abandoning the wagefreezing policy.

We may add, in this connection, that the War Economy Decree also abolished the additional payments for overtime, Sunday, holiday and night work, that all provisions for granting holidays, whether in statutes, wage and plant regulations or individual agreements, were abolished-but that shortly afterwards all these provisions were restored, with the exception of the additional payments for overtime for the $g^{\text {th }}$ and the roth hours. ${ }^{42}$

This whole policy does not seem to have been very successful. The insignificant result achieved by the stabilization of wages will not surprise us, if we consider the social basis of National Socialism. Even the most authoritarian régime, even the placing of SS men behind each worker, will never achieve a maximum of production. The lessons of the coal industry clearly teach that ${ }^{43}$-as well as the migration from agriculture to industry which will be discussed below.

To be sure, no quantitative statements can be made as to how far the undoubted drop in productivity is due to physical exhaustion, to opposition, or to the introduction of over- and under-aged people in the process of production. Yet the incessant strengthening of the terroristic apparatus makes it likely that the slowdown is as important a factor as are physical and economic necessities. The War Economy Decree made it a crime, punishable with imprisonment or even death, to destroy, damage, take away, or hoard raw material or products if by such acts the satisfaction of the population's needs is maliciously impaired. The People's Court had previously ruled that the betrayal of plant secrets may constitute treason to the country and would be punished by death. ${ }^{44}$ The third administrative order ${ }^{45}$ extended the penal power of the Trustees who were authorized to mete out unlimited fines without being compelled to go to the criminal courts.

As compared with the power of the Trustees, that of the Labor Courts is really insignificant. ${ }^{46}$ Their jurisdiction is limited to disputes between an employer and his employees or between employees arising from group work. They still have a

“1 This power was vested in the Trustees in the fall of 1941. See Frankfurter Zeitung, Sept. 28, 194r.

12 See BeheMoth 346-348.

18 Production per shift in the Ruhr valley developed as follows: 1932 (depression year), 2093 kilograms; 1936 (Four Year Plan starts), 2199 kilograms; 1937, 2054 kilograms; 1938, r970 kilograms $(-11 \%)$. This occurred in spite of the fact that the number of miners was increased by 20,000. Even the total production of coal did not adequately develop. 1932, 104.7 million tons; 1936, 158 million tons; 1937, 184 million tons (Saar and Austria included); 1938, 186.4 million tons (Saar and Austria included). See (r939) 48 Soziale Praxis 395.

"Volksgericht (Peoples' Court), First Senate, April 15, I937, in (1937) Zertschrift der Akademte Für DeUTSCHES RECET 410.

1E Issued Dec. 2, 1939, R. G. BL. pt. I, 2370, and I Posse Et al., Kommentar 29-30.

${ }^{4} \mathrm{~A}$ very detailed and accurate study has been made by Cole, National Socialism and the German Labor Courts (1941) 3 J. of Politics 169-197. 
rational organization and a rational procedure. But in actual practice, their limited powers dwindle to almost nothing. For, according to Section Ir of the Labor Courts Act of April ro, $5934,{ }^{47}$ legal representation before the Labor Courts is a monopoly of the Labor Front. Only employees of the Labor Front normally may appear before Labor Courts; members of the bar may appear only in exceptional cases if admitted by the Labor Front. And the Labor Front grants assistance before Labor Courts only if "the intended law suit is (a) expected to be successful, and (b) does not contradict National Socialist principles and the principles of honor of labor." these principles change according to political exigencies, it is almost impossible to say whether a worker or an employer, possessing certain rights, can assert them. ${ }^{40}$

Even less significant are the Social Honor Courts, ${ }^{50}$ intended to punish violations committed by employers and employees against the honor of labor and of the plant community spirit. ${ }^{51}$ They are rarely invoked against employees since the procedure is costly and cumbersome and since the régime possesses cheaper and swifter means of terrorization: the concentration camp, the army, the Todt organization, the People's Courts, the special tribunals. The main purpose of the Social Honor Courts is to terrorize the small businessman who is often unable to cope with the terrific amount of regimentation of the labor market and whose punishment is celebrated as proof of the régime's "social consciousness."

\section{The Labor Front}

Side by side with the state institutions designed to control the labor market, the Labor Front operates as a mere party organization. ${ }^{52}$ It is neither a trade union nor a federation of trade unions, nor a corporate body standing above and between employers and employees. It is rather an inarticulate body comprising all the socalled "Schaffende"53 - that is, all persons engaged in work, workers, salaried employees, free professions, farmers, employers, who are either directly or collectively affiliated. The Labor Front is divided into "Reichsbetriebsgemeinschaften," national plant communities, but these plant communities are not lower organizational units of which the Labor Front is composed,-the members of the Labor Front are not

\footnotetext{
${ }^{4}$ R. G. Br. pt. I, 3I9.

${ }^{4}$ Rechtsschutz-Ordnung der Deutschen Arbeitsfront, c. II, reprinted in RomLFing und Scimaur, Diz ARBeitsGesetze der Gegenwart (Berlin \& Leipzig, r938) 337-340.

${ }^{60} \mathrm{On}$ the legal aid business of the Labor Front, $f$. Werner Hellwig (Director of the Office of Legal Aid in the Labor Front) (1939) 48 Sozrale Praxis 769.

${ }^{\circ}$ They are very accurately analyzed by Pelcovitz, The Social Courts of Honor of Nazi Germany, (1938) 53 PoL. Scr. Q. 350-37r.

"51 They are based on $\$ 535-55$ of the Charter of Labor.

$\varepsilon 2$ The Labor Front is a party organization, under the financial control of the party treasurer, Franz Schwarz. See BehEmoth 80-83. The legislative acts on which its activities are based are: the "Unity Act" of Dec. I, I933, R. G. BL. pt. I, Ior6, as amended on July 3, r934, R. G. BL. pt. I, 529, and the administrative order issued under it on March 29, 1935, R. G. BL. pt. I, 502, as amended on Dec. 5, I935, R. G. BL. pt. I, I523, and Jan. I2, 1938, R. G. BL. pt. I, 36.

${ }^{3}$ Bestimmungen über die Zugehörigkeit zur Deutschen Arbeitsfront, reprinted in Romlfing UND SchraUt, op. cit. supta note $48,333-337$.
} 
members of the plant communities ${ }^{54}$ but solely of the Labor Front as a whole. The plant communities are merely administrative departments of the central administration of the Labur Front. ${ }^{55}$ It is true that ever since 1935 there have existed institutions integrating the Labor Front and the central business organization, the National Economic Chamber, established by the foundation of the National Labor and Economic Council. But this body and its regional and local bases have never once functioned; in fact the sole purpose of their creation by the so-called Leipzig agreement $^{56}$ was to deprive the Labor Front of its economic activities which were entrusted to the National Economic Chamber at the top and to the provincial economic chambers in the middle level.

What then is the Labor Front? It is best to start with what it is not. It is not a union; it does not fix wages or labor conditions; it is not a state organ and thus has no control over labor supply. Its purpose, in the words of the Decree of October 24, 1934, on the Nature and Aim of the Labor Front, ${ }^{57}$ is "the formation of a real people's and performance community of all Germans." It is thus an "educational" institution, a party organ that indoctrinates and terrorizes. All its economic and social functions are derived from authority granted by the state, such as its part in enacting wage regulations, in the legal representation before Labor Courts, in appointing works councils, in checking the remuneration received by home workers, etc. The Labor Front does not shape policies, it only carries out one aspect of the régime's labor policy; it manipulates the workers, drives them on, entices, terrorizes, and indoctrinates them. The role of the Labor Front is best expressed by the Decree of December 28, I939, on the Administration in Rural Units, the manipulation of the masses, to the party. It would be fatally wrong, however, to underestimate this function, which today is more vital than ever before. In a period of slackening performance, population mixture, and military strains, where economic and social necessities forbid the use of economic incentives, the slave driver is the most important figure in the process of increasing output.

It is this job that the Labor Front performs. It operates through its numerous bureaucracy, through its Strength Through Joy Department, and through nonbureaucratic bodies forming élites within the working classes for the purposes of playing off one small group against the mass and of placing stool-pigeons within each plant, shop and public administration. These terrorizing agencies are the

\footnotetext{
sc This point is stressed in the authoritative book by WILIY MÜLLER, DAS SOZIALE LEBEN IM NEUEN Deutschuand (Berlin, I938) 86.

BS There are now 16 such plant communities. Compare, on the organization of the Labor Front, Cole, The Evolution of the German Labor Front (1937) 52 PoL. Scr. Q. 532-558, and Bememoth 4r3-4rg.

${ }^{80}$ On this agreement of March 21, 1935, between the Leader of the Labor Front and the Ministers of Labor and Economics, compare Cole, loc. cit. supra note 55, Berremoth 416-4I7, and BrADY, THE Spirit and Structure of GerMan Fascism (New York, 1937) 127-139.

${ }^{87}$ Reprinted in ROHLFing UND Schraut, op. cit. stipra note $48,327-329$.

t8 See BEHENOTH 72.
} 
Councils of Trusted Men, established on the basis of the Charter of Labor, the Plant Troops, and the Political Shock Troops. ${ }^{\text {"0 }}$

\section{3. "The "Combing-Out Commissions" and the Deputy for Labor Supply}

Yet the machinery consisting primarily of the Ministry of Labor with its labor exchanges and its Trustees, on the one hand, and of the Labor Front, on the other, did not assure a sufficiently streamlined organization for the full control of the labor market. Two more bodies have been created: "combing-out commissions," apparently in the spring of $\mathrm{r} 94 \mathrm{r}$, and a general deputy for labor supply in the spring of I942.

The combing-out commissions ${ }^{60}$ are either national or regional. The former, composed of representatives of the Reich ministries, investigate big plants; the latter comprise representatives of the labor exchange, the armed forces (Rüstungskommandos), the economic offices (Wirtschaftsämter), and the provincial economic chambers. Only rarely do they include a Labor Front official-thus revealing the low regard in which the régime actually holds the Labor Front. The purpose of the commissions is very well defined by their name. They investigate plants, study their output, capacity and the necessity for coordination. If they find that a plant uses labor inadequately or is superfluous in the war effort, the workers are "combedout," that is, ordered to leave and to take work elsewhere. The legislative basis will be discussed later.

The culmination of authoritarian control was reached in the spring of 1942 with the appointment of a general deputy for labor supply who utilizes on the regional level the Gauleiter (district leader) of the party. The appointment was made ${ }^{\text {or }}$ on the authority of the Four-Year-Plan Decree of October $18,193^{6 .}{ }^{62}$ The post parallels that of a general deputy for the rationalization of German industry created shortly before. Fritz Sauckel, district leader of Thuringia, was chosen as the new labor dictator. No better selection could have been made, for Sauckel represents in his person the major groups of the ruling class: industry, party and bureaucracy. $\mathrm{He}$ is an industrialist of no mean standing who controls the National Socialist Party's Wilhelm Gustloff Foundation operating six rich industrial firms. ${ }^{\text {B3 }} \mathrm{He}$ is a party district leader and thereby a powerful party hierarch; he is also a high SS leader (SS Obergruppenführer) and thus belongs to the inner circle of the leadership of the practitioners of violence. He can thus balance the antagonistic forces: the claim of industry for more foreign workers and that of his boss Heinrich Himmler, in his capacity of Reich Commissioner for Strengthening Germanism in the East, for retaining the skilled workers in the East. ${ }^{84} \mathrm{He}$ has the concentra-

${ }^{60}$ For a fuller discussion of these institutions, see BEHEMOTH 422-425, 417-418.

${ }^{\circ 0}$ Sce report in the Frankfurter Zeitung, May I 8, 1941.

${ }^{\text {ox }}$ Decree of March 28, I942, in 6 Der VierJakresplan (1942) 198.

${ }^{62}$ R. G. BL. pt. I, 887. $\quad{ }^{63}$ On the history of this combine, see Benemoti 303-304.

os Exemplified by Administrative Order of the Minister of Labor, May 24, 1940, (1940) RzicusARBEITSBLATT, No. 20, pt. I, 350, in which the Labor Exchanges are ordered to heed the request of Himmler for artisans. 
tion camps at his disposal to punish recalcitrants. He is thus superimposed on the Minister of Labor, Franz Seldte, a nonentity without influence who has been retained merely because German ministers are not makers of policies but simply tools carrying out the commands of the leadership. The district leaders are superimposed on the provincial and local labor exchanges.

The institutional framework for the control of labor in Germany proper is thus complete. We have now to turn to a study of the devices for insuring an adequate labor supply.

\section{Devices for Assuring an Adequate Labor Supply}

The labor supply situation in 1933 , when Hitler came to power, in some ways facilitated, and in some ways obstructed, the execution of the rearmament program. The severe unemployment of the depression period ${ }^{65}$ had created a reserve army from which millions of workers could be transferred into armament production. But the depression had also created very serious handicaps. Skill had been neglected, fewer apprentices had been trained, skilled labor had emigrated, especially from the mines, metallurgical industries, and building construction.

The first tasks were to concentrate labor exchange and to inventory the labor reserve as well as the working population. The Act of November $5,1935,{ }^{68}$ gave the Reich Institute exclusive power over labor exchange, vocational guidance, and the hiring of apprentices. As far as private labor exchange activities were admitted, they were transformed into agents of the Reich Institute. ${ }^{67}$

The inventorying of labor was the second step. The existing statistical services, though much more complete than in the United States, were still inadequate. The number of employed could be approximately estimated on the basis of the contributions to sickness, invalidity, and salaried employees insurance institutions. Unemployment was known through the statistical services of the Reich Institute and of the trade unions. A complete survey of available skill and training was lacking. It was created by the introduction of the work book ${ }^{68}$ for specific industries, which was gradually extended until it covered the whole population with minor exceptions. ${ }^{60}$ The book contains a full vocational record, listing the training, specialization, beginning and end of each employment period, and, in addition, data on air pilot licenses and familiarity with agricultural work. The book has to be handed over to the employer who makes the necessary entries. It is issued to the employee by the labor exchange which transfers the entries on cards. As early as the fall of 1936,22 million books had been issued and the extension in r939 necessi-

\footnotetext{
ot Registered unemployed in January I932: 6.042 million; to this must be added an unknown number of "invisible unemployed," estimated at about 2 million. See BerFiroth 475.

${ }^{08}$ R. G. BL. pt. I, 128r.

${ }^{\circ 7}$ Administrative Order of Nov. 26, 1936. R. G. BL. pt. I, I30r.

${ }^{\text {os }}$ Act of Feb. 26, 1935, R. G. BL. pt. I, 3 II.

${ }^{\circ}$ Decree of April 22, I939, reprinted in F. SyruP, Der Arbertseinsatz IM VIERjartresplan (BerlinVienna-Leipzig, I940) 120-130.
} 
tated the issuance of an additional I4 million books; 8.5 million were issued on June 30, r $\mathrm{r}^{70}{ }^{70}$

\section{The Major Acts and Decrees}

The best way to present the rather complicated legislative development is first to survey the major enactments. ${ }^{71}$ We mention the following:

I. The Act of May 15, 1934, for the Regulation of Labor Supply, ${ }^{72}$ as amended February $25,1935,{ }^{73}$ of which the main provisions authorize

(a) prohibition of the employment of persons not domiciled in the region of their prospective employment;

(b) measures to fight the depletion of agricultural labor supply.

2. The Decree of August 10, I934, for the Distribution of Labor Power ${ }^{74}$ vests the total power of allocation and exchange of labor in the president of the Reich Institute.

3. The Seven Decrees of November $7,1936,{ }^{75}$ dealing with

(a) securing an adequate supply of skilled labor in the new generation;

(b) securing an adequate supply of metalworkers for politically important tasks;

(c) reintroducing metal and building workers into their previous trades;

(d) registering building construction projects before commencement of construction;

(e) reemploying older salaried employees (of 40 years and more);

(f) forbidding the use of code in "help wanted" advertisements; " $^{70}$

(g) granting employers in the metal industry, in building construction, in the brick industry, and in agriculture, the right to retain the work books of workers who leave their positions before the end of the notification period.

4. The Decrees of February $15,{ }^{77}$ and December $23,1938,{ }^{78}$ dealing with agriculural labor and housework;

5. The registration on March $\mathrm{I}, \mathrm{I} 93^{8}$, of students about to leave school; ${ }^{70}$

6. The basic Decree of February $13,1939,{ }^{80}$ establishing conscription of labor and

${ }^{70}$ Beisiegel, Labor Redistribution in Germany (1942) 45 INT. LAB. Rev. No. 4, pp. 395-401. The writer is a high official in the Reich Institute, and his article is a translation of his paper in the "Reichsarbeitsblatt."

${ }^{71}$ Problems of labor time, relief legislation and unemployment support will not be discussed here in this article. Extended discussion of women's labor is also omitted. Cf. Benemorn 341 . The number of employed women in 1933 was 4,700,000, in 1938, 6,300,000, and in January, 1941, 9,400,000. The 2,000,000 added since 1938 came primarily from household work. According to the Census of 1939, supra note 9, there were 21.7 million women without occupation, among whom were 11 million children below fourteen years of age, so that about 1 I million could work. Since the majority is urgently needed for household work, there was in January, 194I, a possible reserve of between 2 and 3 million women. (194I) 20 Die Wirtschaftskurve, No. 2, pp. 148-150. The figures do not say much, since apparently even children are being mobilized.

${ }^{72}$ R. G. BL. pt. I, $3 I$ I.

${ }^{73}$ Id. 3ro. " $I d .786$.

${ }^{75}$ (x936) Deutscher Reichsanzeiger, No. 262, p. I. For this analysis, the author draws on the commentary in SrRur, op. cit. supra note 69.

${ }^{70}$ On Dec. 13, 1940, the Minister of Labor prohibited the use of the press and the radio for "help wanted" ads. (1940) RetchsarbeitsblatT, Nos. 25-36, pt. I, 615.
${ }^{7}$ (1938) Deutscher Reichsanzeiger, No. 43.
70 Id. No. 51.
${ }^{73}$ Id. No. 305.
${ }^{80}$ R. G. BL. pt. I, 206 
restricting the change of employment for certain professions, implemented by administrative orders of March 2 (amended July 27), ${ }^{81}$ March Io, ${ }^{82}$ and July II, I939; ${ }^{83}$ 7. Upon the outbreak of war, the Decree of September I, I939, of the Ministerial Council for the Defense of the Reich. ${ }^{84}$

\section{The Apprentice Problem}

The most serious aspect of Germany's labor supply problem was and still is the lack of a new generation of skilled labor, especially of apprentices. The following table elucidates the gravity of the problem.

\begin{tabular}{|c|c|c|c|}
\hline Year & $\begin{array}{l}\text { Juveniles } \\
\text { leaving school }\end{array}$ & Year & $\begin{array}{c}\text { Apprentice } \\
\text { positions open }\end{array}$ \\
\hline 1934 & $\ldots \ldots \ldots \ldots \ldots \ldots \ldots 6620,000$ & $1933-4$ & . . 155,675 \\
\hline 1935 & . . 620,000 & $1934-5$ & $\ldots 2 \mathrm{Ir}, 790$ \\
\hline 1936 & . . $5^{80,000}$ & $x 935-6$ & 282,290 \\
\hline 1937 & $\ldots 565,000$ & 1936-7 & $\cdot 365,858$ \\
\hline r $93^{8}$ & $\ldots \ldots \ldots 550,000$ & $1937-8$ & $\ldots 44^{1,35^{6}}$ \\
\hline I939 & $\ldots \ldots \ldots 555,000$ & $1938-9$ & n.............. \\
\hline $194^{\circ}$ & $\ldots \ldots \ldots \ldots \ldots \ldots \ldots \ldots \ldots, 550,000$ & & \\
\hline $\mathrm{r} 94 \mathrm{I}$ & . & & \\
\hline I942 & $\ldots \ldots \ldots \ldots \ldots \ldots \ldots \ldots \ldots \ldots \ldots+525,000$ & & \\
\hline 1947 & .................. 444,000 & & \\
\hline
\end{tabular}

Source: Stets, Zur Nachwuchsplanung 194I (1940) ReIchsarbeitsBuAtT, No. 28, pt. V, 482.

The change in the conception of the apprenticeship contract has not increased the apprentice supply; on the contrary, it has decreased it. Under the Weimar Republic, courts and collective agreements had considered the apprenticeship contract not only as an educational agreement but as a genuine labor contract, giving the apprentice all the rights that workers possessed. This achievement was destroyed by National Socialism. The apprentice is no longer considered a worker; his contract is now exclusively an "educational and training agreement." 85

To overcome the scarcity of apprentices, a number of measures have been introduced. Their training period had gradually been shortened until the decree of March 7, 1940 ${ }^{80}$ prohibited any extension beyond three years. ${ }^{87}$ Decree No. 5 of March I, I938, compelled all students up to $2 \mathrm{r}$ years of age leaving elementary, middle, and high schools to register two weeks before graduation with the labor exchange, ${ }^{88}$ while Decree No. $3^{3}$ of November 7,1936 , had already compelled plants

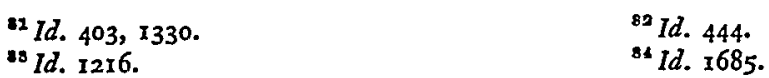

${ }^{85}$ See survey by Theodor Rohlfing, Wandlungen im Lehrverhältnis, in ZeHN JAHRE ARBeitsGericht (Berlin \& Leipzig, r937) 94-104. On the consequences of this change, see BEHEMoth 432-433.

${ }^{86}$ R. G. BL. pt. I, 478; see (I940) 49 Soziale Praxis, No. 7, p. 200.

${ }^{87}$ How serious this step is may be gathered from statistics showing the average length of the training period: Of 190 industrial trades, IO3 had four years training, 4 had $3^{1 / 2}$ years, and 83 had 3 years. Of

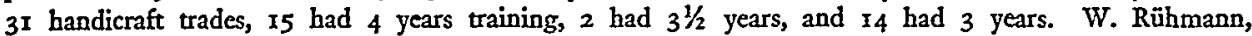
Drei Jahre Lehrzeit (1938) 47 Soziale Praxis, No. 23, p. 1427.

${ }^{88}$ The form is printed in SYRup, op. cit. supra note 69 , at $87 \mathrm{~d}-87 \mathrm{e}$. 
in the iron and steel industries and in building construction with ten and more employed to hire an adequate number of apprentices. ${ }^{80}$

\section{The Agricultural Labor Problem}

The agricultural situation, too, presented grave difficulties. Statistics show a considerable decline of the agricultural population (by $10.6 \%$ from 1933 to 1939) and the "Landflucht"-the flight from agriculture-continues steadily as is shown in No. 17 of the Soziale Praxis of $x 94 \mathrm{r}$ which is exclusively devoted to a discussion of this problem. The flight from the countryside clearly demonstrates the collapse of the "blood and soil" ideology or, more accurately, it results from this policy. For the Hereditary Estates Act which leaves the farm unencumbered to one offspring only, drives the younger sons into industrial work. This, however, is not the sole cause. When National Socialists do not talk propaganda, they are usually intensely realistic and never deceive themselves. They admit that the primary cause of Landflucht is the lower wage scale of agricultural workers who are partly paid in kind (Deputat). The investigation carried out by the Labor Front's Institute for the Science of Labor shows that the German people have no prejudice against the countryside as such, since workers do not migrate from industries located far away from big cities, but that Landflucht occurs exclusively among agricultural labor and is caused by the inadequacy of agricultural wages..$^{90}$

Aside from the introduction of foreign civilian labor and war prisoners, the régime attempted to remedy the situation by the following measures: Act No. I of May 15, 1934, and amended February 25, 1935, gives the president of the Reich Institute the authority to order the dismissal of agricultural workers now employed in other trades; Decree No. $3 \mathrm{~g}$ (of November 7, r936) makes it impossible for agricultural laborers to leave their jobs before the expiration of the dismissal period; Decrees No. $4^{a}$ and $4 b$ of February 15, 1938, and December 23, x938, prohibit the employment of unmarried females below 25 years of age unless they can prove by their work book that they have worked at least one year in agriculture or in a household (Pfichtjahr). ${ }^{91}$ The Pfichtjahr is, however, not the only institution which comprehensively introduces labor into agricultural work. We have to add the Erntehilfe (harvest help) under the auspices of the Hitler Youth for students of ro and more years of age; the Landjahr (agricultural year) for juveniles who are being selected jointly by their school, doctor, labor exchange, national socialist welfare organization and Hitler Youth; the Landdienst (agricultural service) for the re-introduction of urban youth into rural life, organized by the Hitler Youth; ${ }^{22}$ the hauswirtschaftliche Jahr (household year) for female juveniles introduced in

\footnotetext{
${ }^{80}$ Sections 8-10 of the Reichsschulpflichtgesetz of July 6, r938, R. G. BL. pt. I, 799, fixed the compulsory attendance at trade schools at 3 years and, for agricultural apprentices, at 2 years.

${ }^{00} \mathrm{I}$ Jarrauch 1939 (edited by the Arbeitswissenschaftliche Institut der Arbeitsfromt) 389-414, esp. 404-407.

${ }^{\circ 1}$ Ilse Richter, Pflichtjahr fïr Mädchen (1940) Reichsarbertsblatr, No. 26, pt. V, 456.

${ }^{92}$ I938-27,000 juveniles; 1940-18,400 juveniles. See Landeinsatz der deutschen Jugend (I94I) 50 Soziale Praxis No. 17, p. 673.
} 
I934 by an agreement between the woman's organization and the Hitler Youth, intended to train "household apprentices" who have to work in households, work which evokes no enthusiasm since the "apprentices" receive no wages except a little pocket money. ${ }^{93}$ The deterioration of the health of the juveniles must be serious since it is admitted that the average age of the agricultural service boys and girls is steadily dropping. ${ }^{04}$

\section{Metal Industries and Building Trades}

Similar problems existed in the metal industries and in the building trades, and later developed in mining. Decree No. $3^{b}$ of November $7,193^{6}$, tried to solve the difficulty in the following manner. The additional employment of ten and more metal workers ${ }^{95}$ was made dependent upon the consent of the labor exchanges which could grant it only if the work was deemed to be necessary for rearmament. Decree No. $3 c$ of November 7, I936, applied to metal and building workers. It ordered employers to inform the labor exchange whether they employed metal and building workers not actually working in their trade. The labor exchange had then to arrange for a transfer of such workers into their trades. Decree No. $3 \mathrm{~d}$ of the same date ${ }^{\theta 6}$ made it compulsory for private and public building contractors to register building projects above a certain size with the labor exchanges before starting construction.

\section{Labor Freezing and Conscription}

Apart from the three special problems of labor supply (apprentices, agricultural and metal and construction work) the general problem of allocating labor had to be solved. Decree 3 e of November 7 , r936, compelled plants and public authorities with ten and more salaried employees to employ an adequate number of older salaried employees and to inform the labor exchange of the number of employed white-collar workers. ${ }^{97}$ The basic problems, however, were the complete abolition of the freedom to hire and fire and the conscription of labor. Decree No. 6 of February 13, r939, partially solved the first problem. Section II gave the Minister of Labor the right to make the dissolution of labor contracts dependent upon the consent of the labor exchanges. The Minister exercised his right for the following industries: agriculture, forestry, mining (excepting coal mining), chemicals, building materials, iron and metals. Shortly afterwards, coal mining was included. The same decree also authorized him to enact legislation making the hiring of labor dependent upon the labor exchange's permission.

This trend culminated in the war decree (No. 7 of September 1, 1939) which

${ }^{03}$ Else Lüders, Die Dienstpflicht der Frau (1938) id. 47, No. 22, p. 1347; in 1934 there were 3000 household apprentices; in 1935, 12,000; and in 1936, 10,000.

o4 (1941) 50 id. No. 17, p. 673 .

os For exact definition of "metal industry," see SYRuP, op. cit. supra note 69, at 44-47.

os As amended on July 23, 1937. See id. at 62 .

${ }^{07}$ Compare the administrative orders of April 15, 1937, elaborating the procedure and supplying data on the numbers involved. See SyruP, op. cit. supra note 69 , at $77 \mathrm{a}-77 \mathrm{~d}$. 
forbade the dissolution of any kind of labor contract without the consent of the labor exchange and equally allowed the hiring of labor only with the exchange's express permission. Exempted from this latter provision were only agricultural enterprise and mines ${ }^{98}$ and households with children below 14 years of age. The decree of May 20, 1942, finally, vested the right to dissolve a labor contract exclusively in the labor exchanges. The development is thus complete.

The counterpart to the freezing of labor to its place is the introduction of labor conscription by Decree No. 6 of February 13, 1939, which replaced that of June 22, I938. It created the Dienstpflicht, compulsory labor. The labor exchange may conscript "inhabitants of the Reich territory." Aliens are exempt only if international treaties or "recognized rules of international law" provide for such exemptions. Two such types of conscription are distinguished: short-term and long-term service. In the first case, the employer of a conscripted worker has to grant him leave of absence. The labor contract thus does not lapse. In the second case, the old labor contract ceases. In both cases, however, the work of the conscripted worker is carried out on the basis of a labor contract, that is, the moment the labor exchange summons someone to take up work in a plant, a labor contract is considered as having been concluded so that all wage and plant regulations apply to conscripted labor.99 Conscripted workers who are compelled to establish a second household, receive a Trennungszulage (separation bonus) of up to Ig marks a week, ${ }^{100}$ while other regulations provide for support in atypical cases of hardship.

The number of conscripted workers, however, has never been very great. From June 1939 to June $1940,1,750,000$ conscription orders were issued, $1,500,000$ for men, 250,000 for women. From the outbreak of the war to the end of June, r940, only 900,000 short-term conscriptions were issued, ${ }^{101}$ while in June, $1940,350,000$ persons and in I94I, 437,000 men and 174,000 women ${ }^{102}$ were actually conscripted.

Quite a different problem was solved by the Notdienstverordnung, the Emergency Service Decree of October $15, \mathrm{r}_{33} 8 .^{103}$ While labor conscription aims at introducing labor into productive work, the emergency service decree provides labor for meeting public emergencies, such as fire, floods, air raid damages, etc. The tasks are thus "hoheitlich," as German administrative law calls them; they fall in the province of the police. In such emergencies, "inhabitants of the Reich territories" may be summoned to work. Exempt are members of the armed forces,

\footnotetext{
${ }^{18}$ On mines, see Ist Administrative Order of Sept. 6, 1939, R. G. BL. pt. I, 16go; I PossE ET AL., KoMMentar, pt. II, Arbeitsplatzwechsel, I4.

${ }^{20}$ The Ist Administrative Order of March 2, 1939, and July 27, 1939, R. G. BL. pt. I, 403, 1330, contains detailed regulations. See also comments in I POSSE ET AL., KOMMENTAR x x-27.

${ }^{100}$ Administrative Order of Sept. 4, 1939, Deutscher Reichsanzeiger, No. 207, and y Posse ET AL., KOMMENTAR 28-66, where the numerous detailed provisions are printed. The order applics also to cases where workers are transferred due to a shut-down of a plant. See Decree of March 21, 1940, R. G. BL. pt. I, 544 .

101 (1940) 49 Sozinle Praxis, No. 17, 543. $\quad{ }^{102}$ Beisiegel, stipra note 21, at 396.

${ }^{105}$ R. G. BL. pt. I, x44I. The discussion here follows I Posse et al., Kommentar, pt. I, Notdienst, I-53.
} 
the labor service, the custom guards, the police, the "troops at disposal" and the "death-head formations" of the SS, ${ }^{104}$ and some groups in the air raid service. The emergency service is again either a short-term or long-term service. But-in contrast to conscripted labor-it is carried out not on the basis of private but of public law. No labor contract exists between the emergency service worker and his employer. Hence, he receives no wages but support, which is graded according to the income of the emergency service worker ${ }^{105}$ and an equally graded indemnification for clothing, food and shelter. ${ }^{108}$ The notice of July 8 , I939, ${ }^{107}$ designates the offcials who are permitted to request such emergency services. A report of the Frankfurter Zeitung ${ }^{108}$-if I am able to interpret it correctly-shows, however, that the Emergency Service Decree is misused for purposes completely alien to its nature. A new regulation orders especially the offices of the armed forces, of public administration, and of hospitals to dismiss their male personnel and to employ juvenile women workers. The order adds that these girls do not work under a labor contract, that they need not possess work books, and that their marriage is dependent upon consent of the authorities which-so it is added-will be rarely granted.

\section{The Use of Alien Labor and War Prisoners}

It has already been indicated that the mobilization of aliens plays a considerable role in the solution of Germany's difficulties. Three different problems must be distinguished: (I) The importation of foreign civilian labor into the German Reich, partly on the basis of international agreements (i.e., Italy) and partly through conscription, that is, brute force (i.e., Poland); (2) the utilization of war prisoners; and (3) the utilization of labor outside the German territory, that is, in the conquered lands. The three problems must not be confused. The ideological basis of the work by non-Germans is the new conception of international law which has done away with equality and protection of minorities and replaced them by the concept of the "folk group" which allows the German master to differentiate finely among the various national groups so as to give some more, some less, some no rights whatsoever. ${ }^{109}$ The hierarchy is as follows: Jews; Poles; Ukrainians and Croats, Lithuanians, Estonians, Latvians, Czechs, French, Dutch, and Scandinavians; Slovaks; racial Germans without German citizenship; Germans. The hierarchy may change according to political exigencies and has indeed changed, as will be seen below.

\section{The Importation of Foreign Labor}

Within Germany all these groups work. They work on the basis of labor contracts and thus come under the provisions of German labor law and of the wage

${ }^{104}$ On these SS groups, see Венгмотн 69-70.

${ }^{105}$ See the table in I Posse er AL., Koararentar irh.

100 Order of the Minister of the Interior of Oct. 13, 1939 and May 28, 1940, I Posse ET AL., KomMENTAR 38-43.

${ }^{107}$ R. G. Bl. pt. I, 1204, and I Posse et AL., KoMMmentar 12.

${ }^{108}$ Frankfurter Zeitung, Aug. 17, 194I.

${ }^{100} \mathrm{Cf}$. BEHEMOTH 160-171, 125-127. 
and plant regulations, with certain exceptions. Jews are-in violation of the racial theory-drafted and work under labor contracts. They are nevertheless subject to special restrictions. The Reich Supreme Labor Court had already ruled that Jews cannot become members of the "plant community,"110 and a ruling of the Minister of Labor clarified their legal position, ${ }^{111}$ drawing the consequences from their exclusion from the plant community. They may not be appointed foremen, and do not receive wages on holidays (Mayday, New Year, Christmas, etc.). They are not entitled to family allowances, nor to pregnancy bonuses, nor may they receive dismissal indemnities and separation bonuses ${ }^{112}$ if their wages are high enough. They cannot get Christmas or other bonuses, nor have they the right to demand wages in case of air raid alarm. Only once a year may they go home to their families. They are subject-as are the Poles-to a Sozialausgleichabgabe, a special additional tax of $15 \%$ of the wage exceeding 39 marks monthly. ${ }^{113}$

This treatment meted out to Jews and Poles has, however, been extended in the spring of 1942 to all "folk groups" in the territory of the Generalgoutvernement (occupied Poland). The preferential treatment of the Lithuanians, Latvians, Estonians and Ukrainians has ceased. They are now also subject to the $15 \%$ tax and are placed-whatever their training and skill may be-in the lowest wage class of their age and occupational group. Also all the other regulations applied to Jews are now applied to them. Only in one instance is their treatment better. They are taxed according to the size of their families whereas in the case of the Poles no such consideration is shown. ${ }^{114}$

Even this limited amount of rights is not applied to the inhabitants of occupied Russia. To Russians German labor law does not apply, even if they work inside Germany. The sole protection that the Minister of Labor found necessary to enact in their behalf was that deductions from their wages should be made in such a way that the workers retain, if possible, 20 Pfennigs per working day as pocket money. ${ }^{116}$ Jews have to wear the Star of David, Poles a P, and Russians an O (meaning OstEast) on their sleeves. In order to counteract any sentimental feelings that decent German employers or civil servants may have toward these slaves, the Minister of Labor added: "It is the duty of the labor commissioner to watch that these workers are not, directly or indirectly, granted better working conditions then prescribed by the existing regulations."116

\section{The Utilization of War Prisoners}

The work of war prisoners does not come under the provisions of German labor law. It is slave labor pure and simple. Wages that have to be paid so as not to ${ }^{110}$ Judgment of July 24, 1940 (1940) Deursche Justiz, No. 37, 1035.

${ }^{111}$ Dr. Hans Küppers, Die vorläufige arbeitsrechtliche Behandlung der Juden (1941) ReichsıronirsBLATT, No. 6, pt. V, го6.

212 Ibid.

${ }^{113}$ Decree of Dec. 24, 1940, R. G. Br. pt. I, 1666; (1940) Reichsarbeitsbentr, No. 24, pt. I, 446. ${ }^{124}$ Order C III b, 3972/42 of Feb. 27, 1942, reprinted in 1. T. F. Bull., No. 9, Fascism, May 4, 1942. ${ }^{136}$ Ibid. 110 lbid. 
prefer one entrepreneur to another, are paid to the Stalag, the administration of the war prisoners camps. According to a ruling of the Minister of Labor ${ }^{117}$ war prisoners shall be employed in the following occupations and, if possible, in the following sequence: agriculture; melioriation; mining; railroad track work; construction and operation in synthetic rubber; hydrogenation and cellulose wool plants; roads and canals; brick factories and quarries; stable construction; turf work; transportation. Special labor exchange offices have been set up to find out the amount of skilled labor that is available. ${ }^{118}$

In spite of the political dangers involved, even Russian war prisoners have been set to work in Germany.

\section{The Utilization of Labor in Occupied Countries}

It is impossible to adequately describe the varied labor regulations prevailing in the occupied territories. They differ from country to country. In Poland and Russia they are plain slavery regulations, while in other parts of Europe attempts are still being made to establish Fascist- and German-dominated unions or labor fronts that help to enslave the working classes. The Bulletin of the International Transport Workers Federation on "Fascism" provides reliable material in abundance. ${ }^{119}$

\section{FutuRe Trends}

We have by no means covered the whole territory. Nothing has been said about the development of wages and the material and non-material gratification that the working class received. I have to refer the reader to my book and to a future study of these problems. It may suffice here to indicate the major trends in broad strokes. Wages have, as a rule, been stabilized on the depression level while in many cases (building construction) reductions have been made. Earnings have increased as a result of longer hours of toil-as National Socialists themselves admit. Deductions for taxes, contributions to social insurance institutions, Labor Front, party, and winter help average at least $26 \%$, probably more. ${ }^{120}$ Prices of consumption goods have slowly but steadily risen; compulsory saving has been introduced; accidents rise and physical exhaustion has begun to show. Income from wages and salaries fell steadily as compared with income from other sources.

A study of National Socialism reveals the picture of a terrorized, fully exploited working class. Had we the space, we could show by a number of instances that even the complete terrorization of the working classes by state and party has not

217 (1940) Reichsarbeitsblatt, No. 21, pt. I, 384 .

${ }^{118}$ Id. 530, and Hölk, Der Einsatz von Kriegsgefangenen in Arbeitsstellen (1940) ReICHSARBEitsBLATT, No. 21, pt. V, 353 .

210 The main lines of this policy are described in Benemotr $17 \mathrm{r}-\mathrm{r} 83$, and by Ernest Hediger, Nazi Exploitation of Occupied Europe, Foreign Policy Rep., June r, 1942, which also contains an excellent bibliography.

120 On wages, see (1940) 49 Soziale Praxis, No. 7, 223; on earnings, see (1940) Reichsarbeitsblatt, No. $30, \mathrm{pt} . \mathrm{V}, 530$; on deductions, see Charlotte Lorenz, Verbrauchs-Haushalt und öffentlicher Haushalt (1938) 47 Sozinle Praxis, No. 19, I197, 
succeeded in completely suspending the laws of the labor market. The decline of production in coal mining and the subsequent legislation to increase productivity; ${ }^{121}$ the migration from agriculture; the abolition of holidays, of overtime, night and holiday bonuses and their subsequent reintroduction; ${ }^{122}$ Hitler's blast at the "acquired rights" of the German workers in his last speech and the appointment of Sauckel; innumerable devices of employers to improve the conditions of their workers-they all demonstrate that authoritarian control of the labor market, even where the means of violence are fully centralized, does not produce the best results. A democracy will not follow this course-for reasons both ideological and materialistic.

A number of probable consequences must be mentioned to round off the picture. The aims of National Socialism are clear. Dr. Friedrich Syrup, the former president of the Reich Institute and Secretary of State in the Labor Ministry, has frankly stated them: de-industrialization of the occupied territories and concentration of industrial production in Germany. The millions of workers from occupied Europe will have to continue to work for Germany. But-so Dr. Syrup insists-this "migration must not lead to a settlement of foreigners, to an unnatural mixing of European peoples and races." Therefore, the foreign workers must be separated from their families and see them only occasionally. ${ }^{123}$

The future New Order is thus nothing but the perpetuation of war conditions on a much larger scale. It is an order of slavery, tyranny and brutality. It is impossible to express in words the sufferings and the heroism of the exploited peoples.

One day this system will be destroyed from without and within. Will it be followed by a new nationalism? Will the outcome of the National Socialist New Order be a return to Igth-century nationalism? We believe the very opposite. Nationalism is in decay. The exploitation of the masses in Germany and Europe is not merely the work of the German ruling groups, of the party, army, big business and the high bureaucracy. Native capitalists, landowners and Fascists share the guilt and the spoils. Considerable sections of the native ruling classes have made their peace with the German conqueror and have even actively helped the conquest. The masses in Europe know that their terrorization is European and not merely German.

There is a second factor. The mass migration of foreign workers into Germany creates an entirely new political and psychological situation. Common work and common exploitation creates solidarity. Fraternization is frequent, partly out of pity, partly for political reasons, and the draconic punishment meted out for it merely illustrates the dread of the German conqueror before the common power of the European working classes.

\footnotetext{
121 See BEHEMOTH 344-345. $\quad$ Is $I d .346-348$.

${ }^{223}$ (1941) Reichsarbertsblatt, July 15, quoted from I. T. F. Bull. No. 16, Fascism, Aug. 5, I941.
} 